\title{
Simulation of Evacuation from Mine as a Safety Measurement
}

RADOJE B. JEVTIĆ, School for Electrical Engineering „Nikola Tesla“, Niš

Review paper

$U D C: 622.86$

DOI: 10.5937/tehnika2001110J

\begin{abstract}
Mines present places where different ore or minerals can be exploited for industrial requirements. Mine can be on surface and deep underground. Mines are opening at the location where ore or minerals can be found in increased amount, enough to economically justify their exploitation. Underground mines were realized mostly for more valuable materials, such as diamonds, gold, silver, uranium, coil etc. In order to reach the raw materials, many underground rooms must be dug, such as shafts, galleries and similar. Although many safety measures were taken, mine accidents do occur in mines, and take many casualties. One of the most important things if the accident happens is the evacuation. Injured miners must be removed from the mine as soon as possible. Any mistake during evacuation can lead to an increase in the time required for evacuation and very often to new accidents. This paper was written to show an example of evacuation from underground mine.
\end{abstract}

Key words: mine, evacuation, simulation, safety

\section{INTRODUCTION}

For centuries, mines present very important sources of different materials with great importance for industry and economy, such as gold, silver, diamonds, coal, iron, cooper, nickel, titanium, lead, uranium, different types of salt, oil, cobble, marl, alumina, gypsum etc. Mine must be economically justify and payable. Mines can be landline or underground. The examples of landline mine and underground mine are presented on figure 1 .

Although a large number of safety measures are applied in mines, accidents in mines are very often and caused many human victims.

According to some investigations, in the twelve the biggest accidents in mines in the world, 6811 miners were killed. In December 1866, in England, in Okasu, 361 miners were killed. In 1906, in France, in Courrieres mine, 1099 miners were killed. In mine Monongah, in USA, in December 1907, 361 miners were killed. Mine accident in Senghenydd, in Great Britain, in October 1913, took 439 lives. Mine accident in Mitsubishi Hojyo, in Japan, in December 1914, took

Author's address: Radoje Jevtić, School for Electrical Engineering „Nikola Tesla“, Niš, Aleksandra Medvedeva 18

e-mail: milan.jvtc@gmail.com

Paper received: 27.01.2020.

Paper accepted: 04.02.2020.
687 lives. The biggest mine accident in the world was in China, in 1942 in mine Honkeiko, where 1549 miners were killed.

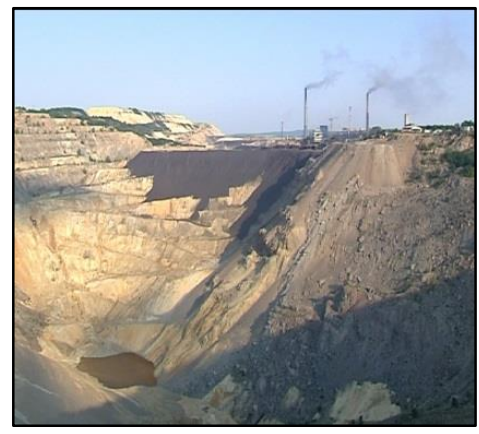

a)

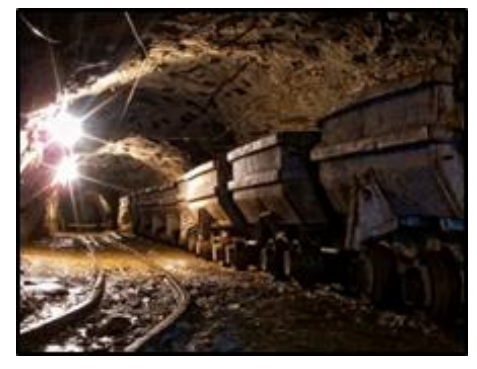

b)

Figure 1 - The examples of landline mine a) (figure source: https://bormojgrad.wordpress.com/) and underground mine b) (figure source: https://www.blic.rs/biznis/vesti/Zlato-bakar-ilignit-kopamo-na-200-lokacija-u-srbiji-aovo-je -detaljna - mapa -naseg/ct5229s). 
Among the greatest accidents in mines was also the accident that occurred in mine Laobaidong, in Chinese province Shanzi, in May 1960, when 684 miners were killed. In 1963, in Japan in mine Mitsui Miike, 458 miners were killed while 833 miners were injured. The mine accident that occurred in mine Dhori, in Jharkhand province in India, in 1965, 375 miners were killed.

Mine accident in Zimbabwe, in 1972, 426 miners were killed. Mine accident in mine Chasnala, in India, in 1975, took 372 lives. In Soma mine in Turky, in May 2014, fire occurred in the moment when 787 miners were inside the mine, 205 miners were killed, while the number of injured was 86 miners [1].

In Serbia, there were also several mine accidents that took many victims. In Senj mine near Ćuprija, in July 1893 , there was a collapse of a wooden beam on the miners in the mine. In that time, no employee records were kept, but, according to some sources, the number of killed miners was from 28 to 55 . A fire that engulfed the forest and carried on the pit caused the collapse of wooden beam.

In 1983, in mine in Aleksinac, accident that was occurred took five lives. The cause for accident was an explosion of methane.

In Rembas mine in Resavica, in 1984, 34 miners were killed. The cause for miner's death was the failure on electrical net what stopped the ventilation.

In November 17, 1989, terrible accident was occurred in Aleksinac mines. The occurrence of fire was in the depth of 700 meters, in the northern part of the pit. This accident caused by neglect-the fire was caused welders during the improper removal of one rail, using an autogenous welding machine. The number of killed miners was 90 . After this accident, for more than 100 years of its existence, mine was closed. The biggest coal production mine realized in 1963, when from its six parts 444007 tons of coal were produced [2, 3]. In former SFRJ, the biggest accident in mine was in Mramor, in Bosnia and Herzegovina, in 1990. An explosion in the „Dobrnja Jug” pit, in Kreka mine took 180 lives. The average age of miners was 27 years! The cause for an explosion was coal dust that caught fire. Only one miner survived [4].

The accidents in mines were caused by several factors, such as methane, carbon monoxide, sulphur hydrogen, coal dust, interruption of power supply, collapse, water flow and similar. Methane $\left(\mathrm{CH}_{4}\right)$ presents very flammable and explosive gas that belongs to the alkane group. The explosion of methane occurs when methane, as a product of coal, comes into contact with some fire source, without enough presence of air that could dilute mixture below the lower explosive limit.
Although the explosive field of methane is not very „wide" (between $5 \%$ and $14 \%$ ), as it can be seen on figure 2, explosions of methane in mines are very often and cause many victims. Methane is lighter than air and because of that reason, it is located in upper layers of pits. According to the hazard level and the necessity to take preventive measurements, the mining pits can be classified into three categories: the first category, where the occurrence of methane is lower than $5 \mathrm{~m}^{3}$ per average daily production ton; the second category, where the occurrence of methane is from 5 to $10 \mathrm{~m}^{3}$ per average daily production ton and the third category, where the occurrence of methane is bigger than $10 \mathrm{~m}^{3}$ per average daily production ton. The occurrence of methane in mines is not connected with geology position. Methane is present in nature everywhere where organic material is subjected to decay without the presence of air. Methane penetration into the pits occurs during pits operations. The speed of methane penetration into pit depends from permeability of coal and surrounding rocks. The possibility of methane penetration into pits increases with depth increasing. The great role on methane penetration and quantity has barometer pressure. The ignition temperature of methane mixture with air is about 650 to $660{ }^{\circ} \mathrm{C}$. On temperature from $1000{ }^{\circ} \mathrm{C}$, the ignition of methane mixture with air is incredible fast. The ignition temperature of optimal mixture of methane and air $(9,5 \%)$ is $2650{ }^{\circ} \mathrm{C}$. With approaching to the explosive limits (5\% and $14 \%$ ), that temperature becomes lower and reaches $1500{ }^{\circ} \mathrm{C}$ [5-8].

A common occurrence in mines is also a mixture of carbon monoxide and air. Carbon monoxide presence is everywhere where there is no enough quantity of air. This gas is also lighter than air and can be found in the upper layers of pits. It is very explosive; it's explosive field is very wide (from $12,5 \%$ to $75 \%$ ) as it is presented on figure 2. Beside that fact, carbon monoxide is very toxic and lethal even it does not explode and there is no insight into its presence. The strongest explosion of carbon monoxide is when the mixture contents $28,6 \%$ of carbon monoxide. A mixture of sulphur hydrogen with air in mines is also common occurrence. The rotting of materials that contain sulphur generates this gas. This gas has characteristic smell on spoiled eggs and it is very toxic; it's explosive field (from 5,4\% to $45 \%$ ) is also presented on figure 2.

In the mines where potassium and rock salt are exploited, a mixture of hydrogen and air can occur. Ignition temperature of hydrogen is about 580 to $590^{\circ} \mathrm{C}$ and it`s explosion field is very wide (from $4,1 \%$ to $74,2 \%$ ), as it is presented on figure 2 . This gas is not toxic, but it`s presence can amplify the methane explosion. 


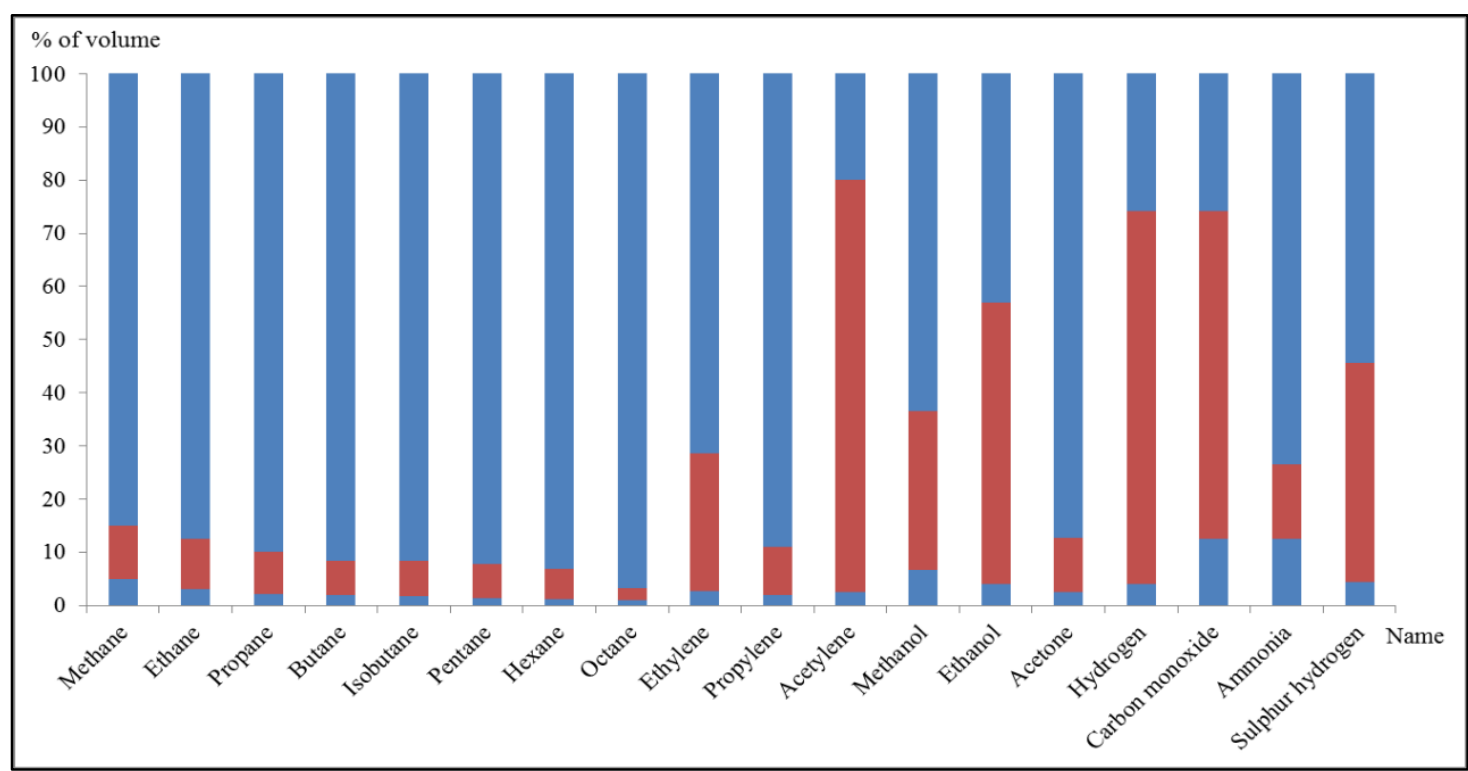

Figure 2 - Explosive bounds of gases and vapors in the air and explosion fields presented in \% of volume (figure source: Jevtić, $R$. and Blagojević, M.: Installation of Carbon Monoxide Detectors, Tehnika Elektrotehnika, Vol 1, pp. 152-158, ISSN 0040-2176, Belgrade, Serbia, 2019.)

In addition, other gases can cause or participate in an explosion.

Table 1. Parts of gases in mines related to analyses (table source:
Parts of gases in mines related to analyses are presented in table 1.

http://tehnika.lzmk.hr/tehnickaenciklopedija leksplozije_u_rudnicima.pdf)

\begin{tabular}{|c|c|c|c|}
\hline \multirow{2}{*}{ Gas } & \multicolumn{3}{|l|}{ Part of gas $(\%)$} \\
\hline & the biggest & the smallest & the most frequent \\
\hline $\mathrm{CH}_{4}$ & 95 & tracks & 2 \\
\hline $\mathrm{N}_{2}$ & 93 & 2 & 78 \\
\hline $\mathrm{CO}$ & 6 & tracks & 1 \\
\hline $\mathrm{O}_{2}$ & 20.5 & 9 & 19 \\
\hline $\mathrm{CO}_{2}$ & 9 & 0.1 & 8 \\
\hline $\mathrm{H}_{2}$ & 5 & tracks & 1 \\
\hline
\end{tabular}

Coal dust, as many other kinds of dust, can be very danger in the sense of fire and explosion. This dust can occur in every mine where coal layers are dry and prone to milling. Coal dust can be consequence of pits works. It is very fine and it can be easily twisted with the smallest occurrence of airflow. Coal dust with the presence of methane significantly increases possibilities and conditions for an explosion.

Very often occurrence is that gas explosion swirls the dust, which forms a mixture with air and causes a new explosion. According to some theoretical calculations, the strongest explosion will occur at a dust concentration of $112 \mathrm{~g} / \mathrm{m}^{3}$. The reason for that is the fact that all coal dust will mix with complete oxygen from air and produce the temperature of 2492 ${ }^{\circ} \mathrm{C}$.

The interruption of power supply in the most cases causes ventilation to stop and leads to suffocation.
However, no matter what caused accidents in the mines, mines present very hard objects for evacuation, especially if an accident has already occurred. Despite all the safety measures that have been taken, it is almost impossible to always anticipate the consequences of a mine accident and apply an appropriate evacuation strategy. As an example, when the accident occurred in Aleksinac mines, it took more than 25 days after the accident for the dead miners' bodies to be brought to the surface.

Therefore, it was obvious that evacuation from these kinds of objects must be carefully and detail prepared. One of the safest, cheapest, and most effective ways for prediction and preparing of evacuation is the usage of the simulation software. This paper was written to show the usage of Pathfinder simulation software in prediction of evacuation scenarios and calculating of evacuation times. 


\section{PATHFINDER SIMULATION SOFTWARE}

Pathfinder presents power simulation software intended for simulation of evacuation situations as well as $2 \mathrm{D}$ and $3 \mathrm{D}$ presentation of simulation results. This software was designed to calculate evacuation times needed for evacuation from different kind of objects with its real dimensions. The first step in simulation of evacuation is to create an appropriate simulation model with its real dimensions and other factors and parameters that can affect to evacuation time (exits, doors, elevators, stairways and similar). Every occupant in particular object was defined by its position in object, its profile (size, speed and similar) and its behaviour during the evacuation. Occupants can be showed originally as people or as cylinder, as disks or as generic.

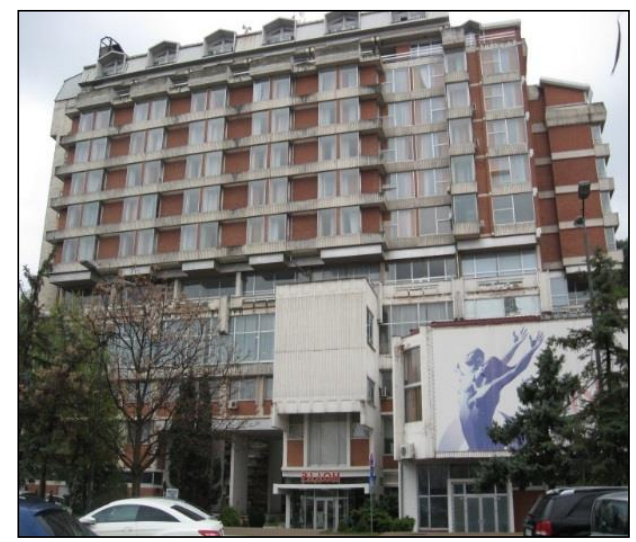

a)
This simulation software supports two simulation modes of movement. The first mode is so called „Steering" mode and in this mode occupants use a steering system for moving and interacting with other occupants. The second mode, so called „SFPE” mode is a mode where occupants in object do not attempt to avoid one another and where some limits related to flow through doors and velocity exist.

This software, of course, needs powerful hardware configuration for cosy and undisturbed work, what implies, as an example, minimum of 4 GB of RAM and Intel Core $\mathrm{i} 3$ or similar processor. The more RAM memory and the stronger the processor will provide faster work [9]. The presentation of particular object and its Pathfinder presentation are presented on figure 3 , as a and $b$.

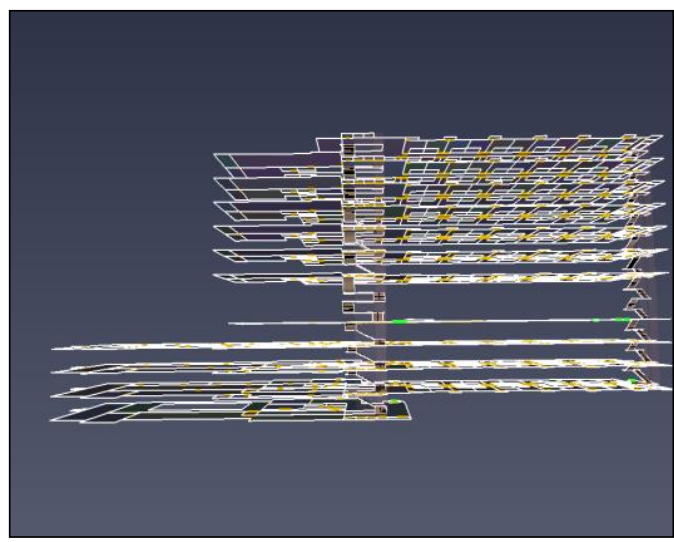

b)

Figure 3 - The presentation of particular object (a) and its Pathfinder presentation (b) (figures source: Jevtić, B. R.: Simulation Of Evacuation Situations In Order To Protect Human Lives And Material Property, NBPJournal of criminalistics and law, No. 2, pp. 35-49, ISSN 0354-8872, UDC 343.98, Belgrade, Serbia, 2016.)

One of the very important and appropriate software potentials is the potential of importing files created in other simulation software, such as 3D CAD, FDS and PyroSim. The usage of these kinds of files significantly saving times needed for designing of the simulation model of the object. There were several versions of Pathfinder. Newer versions of this simulation software enable creating evacuation scenarios of immobile occupants, such as occupants in medical chairs and medical beds. Version of Pathfinder simulation software used for the purposes of this paper was 2019.

\section{SIMULATION MODEL}

Simulation model for this paper is presented as mine with different depths and different number of corridors. The depths that simulation of evacuation was realized on were 150, 400 and 700 meters. The number of corridors was four and one. The first case implied simulation of evacuation from noted depths when occupants had speeds from $0.1 \mathrm{~m} / \mathrm{s}, 0.2 \mathrm{~m} / \mathrm{s}, 0.35$

$\mathrm{m} / \mathrm{s}, 0.5 \mathrm{~m} / \mathrm{s}$ and $0.75 \mathrm{~m} / \mathrm{s}$. There were two elevators with maximal capacity of 25 persons each. The dimensions of elevators were $3 \mathrm{~m} \times 2.5 \mathrm{~m} \times 2 \mathrm{~m}$. The speeds of these elevators were $5 \mathrm{~m} / \mathrm{s}, 7 \mathrm{~m} / \mathrm{s}$ and $10 \mathrm{~m} / \mathrm{s}$. The occupants were located randomly into four different corridors, $4 \mathrm{~km}$ long, 2 meters high and 2 meters wide each. There were nine different scenarios. The Pathfinder simulation model for the first case is presented on figure 4 (a).

The second case implied simulation of evacuation from noted depths when occupants had speeds from $0.1 \mathrm{~m} / \mathrm{s}, 0.2 \mathrm{~m} / \mathrm{s}, 0.35 \mathrm{~m} / \mathrm{s}, 0.5 \mathrm{~m} / \mathrm{s}$ and $0.75 \mathrm{~m} / \mathrm{s}$. There were two elevators with maximal capacity of 25 persons each. The dimensions of elevators were $3 \mathrm{~m} \mathrm{x}$ $2.5 \mathrm{~m} \times 2 \mathrm{~m}$. The speeds of these elevators were $5 \mathrm{~m} / \mathrm{s}$, $7 \mathrm{~m} / \mathrm{s}$ and $10 \mathrm{~m} / \mathrm{s}$. The occupants were located randomly into one corridor that was $4 \mathrm{~km}$ long, 2 meters high and 2 meters wide. There were nine different scenarios. The Pathfinder simulation model for the second case is presented on figure 4 (b). The reason for 
selected occupants speeds was in the fact that the corridors in mines are often narrow and poorly

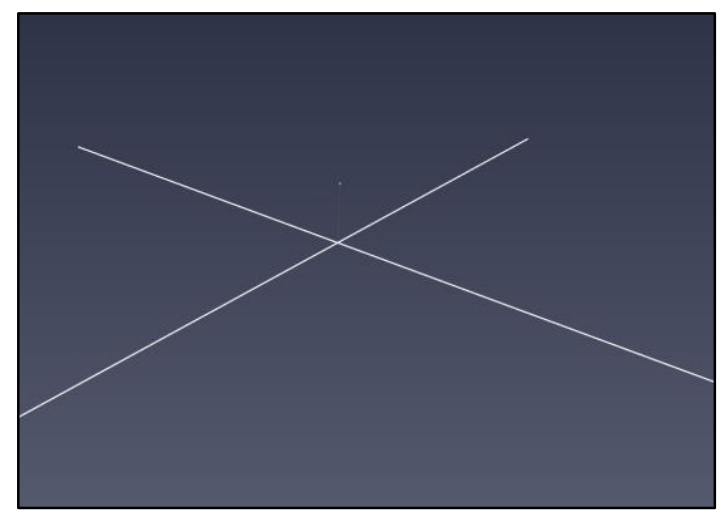

a) accessable, with the presence of necessary equipement and wagons for ore.

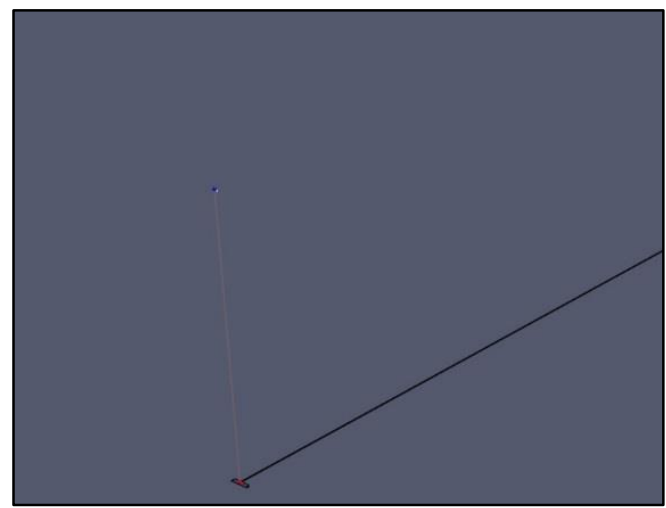

b)

Figure 4 - The Pathfinder simulation model for the first case with four corridors (a) and the Pathfinder simulation model for the second case with one corridor $(b)$

\section{SIMULATION RESULTS}

Simulations were realized on computer equipped with Intel(R) Pentium (R) CPU G400 @ 3.30 GHz, with 4 GB RAM. There were eighteen simulations

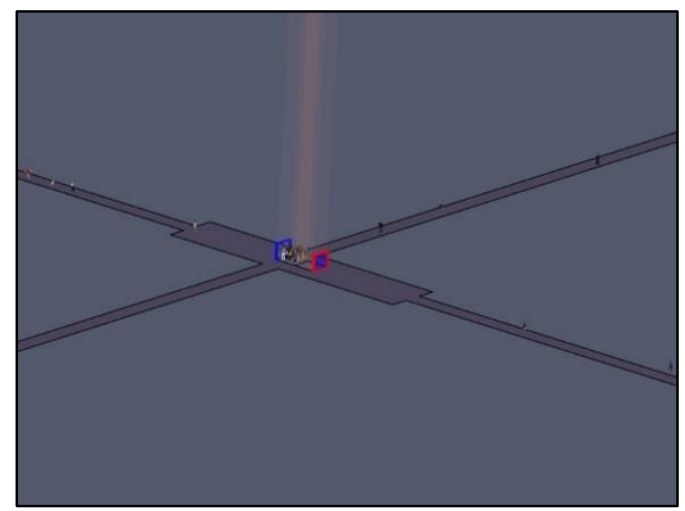

a) realized. The average time of simulation realization was about 46 minutes. Some of the simulation moments were presented on figures 5 and 6 (under a and b) while the simulation results were presented on tables from 2 to 19 .

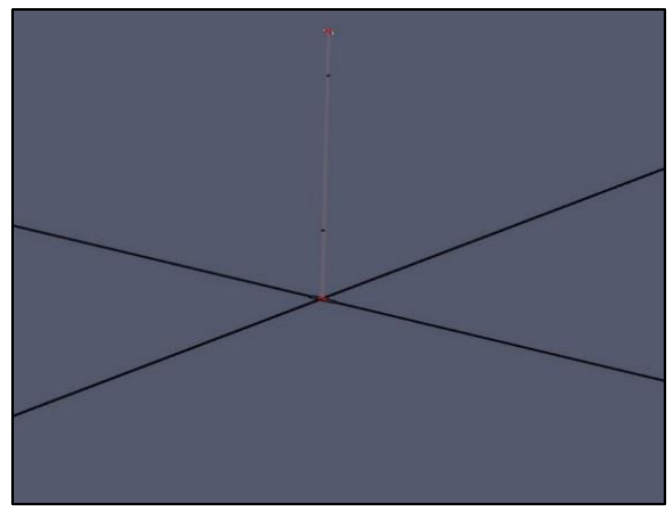

b)

Figure 5 - Simulation moments from the first scenario, for the occupant speeds from $0.2 \mathrm{~m} / \mathrm{s}(\mathrm{a})$ and for the occupant speeds from $0.7 \mathrm{~m} / \mathrm{s}$ (depth for both cases was 400 meters)

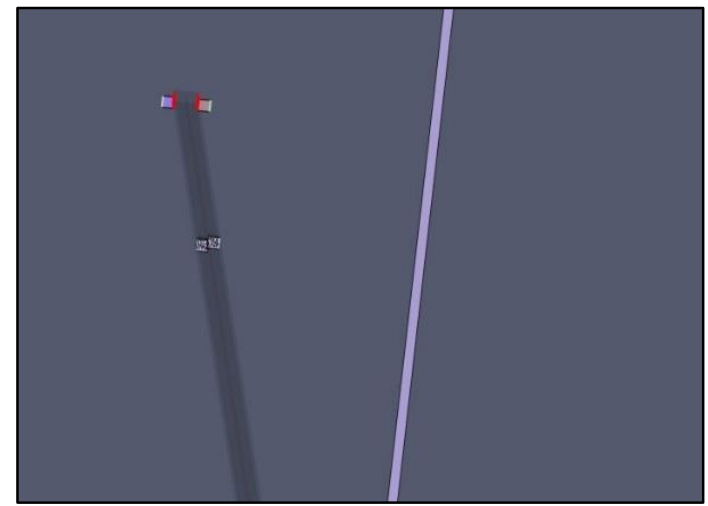

a)

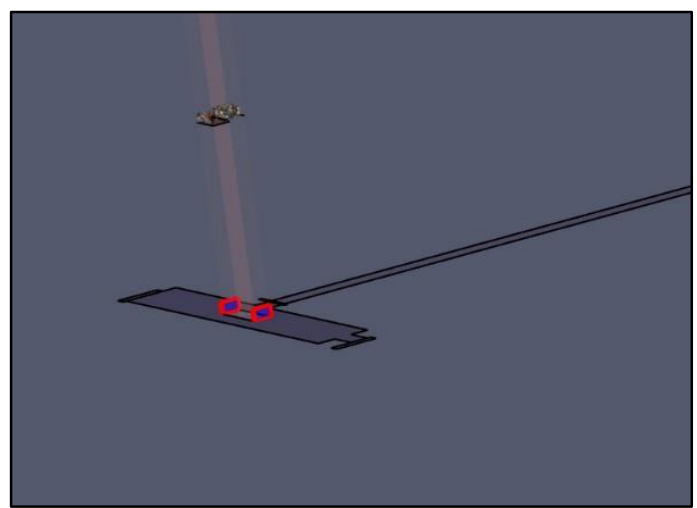

b)

Figure 6 - Simulation moments from the second scenario, for the occupant speeds from $0.5 \mathrm{~m} / \mathrm{s}(\mathrm{a})$ and for the occupant speeds from $0.7 \mathrm{~m} / \mathrm{s}$ (depth for both cases was 700 meters) 
Table 2. Simulation results in minutes for the first case, from the depth of 700 meters, for the elevator's speed from 10 $\mathrm{m} / \mathrm{s}$ and for the occupants speeds from $0.1 \mathrm{~m} / \mathrm{s}, 0.2 \mathrm{~m} / \mathrm{s}, 0.35 \mathrm{~m} / \mathrm{s}, 0.5 \mathrm{~m} / \mathrm{s}$ and $0.75 \mathrm{~m} / \mathrm{s}$

\begin{tabular}{|l|l|l|l|l|l|l|l|}
\hline Number of occupants & 120 & 100 & 80 & 60 & 40 & 20 & 0 \\
\hline Speeds of occupant from $10 \mathrm{~cm} / \mathrm{s}$ & 0 & 126.15 & 219.78 & 320.17 & 446.33 & 564.97 & 666.92 \\
\hline Speeds of occupant from $20 \mathrm{~cm} / \mathrm{s}$ & 0 & 66.55 & 112.98 & 161.02 & 225.98 & 283.77 & 334.98 \\
\hline Speeds of occupant from $35 \mathrm{~cm} / \mathrm{s}$ & 0 & 38.98 & 65.47 & 93.33 & 129.90 & 162.12 & 192.73 \\
\hline Speeds of occupant from $50 \mathrm{~cm} / \mathrm{s}$ & 0 & 27.87 & 46.22 & 65.68 & 91.78 & 114.58 & 135.83 \\
\hline Speeds of occupant from $75 \mathrm{~cm} / \mathrm{s}$ & 0 & 20.48 & 32.18 & 44.93 & 60.90 & 77.02 & 91.57 \\
\hline
\end{tabular}

Table 3. Simulation results in minutes for the first case, from the depth of 700 meters, for the elevator's speed from 7 $\mathrm{m} / \mathrm{s}$ and for the occupants speeds from $0.1 \mathrm{~m} / \mathrm{s}, 0.2 \mathrm{~m} / \mathrm{s}, 0.35 \mathrm{~m} / \mathrm{s}, 0.5 \mathrm{~m} / \mathrm{s}$ and $0.75 \mathrm{~m} / \mathrm{s}$

\begin{tabular}{|l|l|l|l|l|l|l|l|}
\hline Number of occupants & 120 & 100 & 80 & 60 & 40 & 20 & 0 \\
\hline Speeds of occupant from $10 \mathrm{~cm} / \mathrm{s}$ & 0 & 121.35 & 217.15 & 340.90 & 467.03 & 560.05 & 671.02 \\
\hline Speeds of occupant from $20 \mathrm{~cm} / \mathrm{s}$ & 0 & 64.87 & 111.65 & 159.27 & 223.87 & 281.50 & 320.00 \\
\hline Speeds of occupant from $35 \mathrm{~cm} / \mathrm{s}$ & 0 & 37.78 & 64.65 & 91.48 & 126.08 & 159.05 & 187.97 \\
\hline Speeds of occupant from $50 \mathrm{~cm} / \mathrm{s}$ & 0 & 26.53 & 47.28 & 64.77 & 89.13 & 114.95 & 134.75 \\
\hline Speeds of occupant from $75 \mathrm{~cm} / \mathrm{s}$ & 0 & 17.07 & 31.47 & 43.50 & 59.98 & 77.92 & 90.27 \\
\hline
\end{tabular}

Table 4. Simulation results in minutes for the first case, from the depth of 700 meters, for the elevator's speed from 5 $\mathrm{m} / \mathrm{s}$ and for the occupants speeds from $0.1 \mathrm{~m} / \mathrm{s}, 0.2 \mathrm{~m} / \mathrm{s}, 0.35 \mathrm{~m} / \mathrm{s}, 0.5 \mathrm{~m} / \mathrm{s}$ and $0.75 \mathrm{~m} / \mathrm{s}$

\begin{tabular}{|l|l|l|l|l|l|l|l|}
\hline Number of occupants & 120 & 100 & 80 & 60 & 40 & 20 & 0 \\
\hline Speeds of occupant from $10 \mathrm{~cm} / \mathrm{s}$ & 0 & 125.97 & 213.97 & 345.95 & 465.93 & 561.52 & 672.30 \\
\hline Speeds of occupant from $20 \mathrm{~cm} / \mathrm{s}$ & 0 & 65.52 & 111.08 & 174.60 & 235.48 & 282.67 & 338.92 \\
\hline Speeds of occupant from $35 \mathrm{~cm} / \mathrm{s}$ & 0 & 38.80 & 63.73 & 101.67 & 137.02 & 162.77 & 192.87 \\
\hline Speeds of occupant from $50 \mathrm{~cm} / \mathrm{s}$ & 0 & 30.00 & 46.63 & 71.75 & 96.95 & 115.87 & 137.07 \\
\hline Speeds of occupant from $75 \mathrm{~cm} / \mathrm{s}$ & 0 & 20.08 & 32.73 & 49.67 & 65.17 & 78.83 & 94.10 \\
\hline
\end{tabular}

Table 5. Simulation results in minutes for the first case, from the depth of 400 meters, for the elevator's speed from $10 \mathrm{~m} / \mathrm{s}$ and for the occupants speeds from $0.1 \mathrm{~m} / \mathrm{s}, 0.2 \mathrm{~m} / \mathrm{s}, 0.35 \mathrm{~m} / \mathrm{s}, 0.5 \mathrm{~m} / \mathrm{s}$ and $0.75 \mathrm{~m} / \mathrm{s}$

\begin{tabular}{|l|l|l|l|l|l|l|l|}
\hline Number of occupants & 120 & 100 & 80 & 60 & 40 & 20 & 0 \\
\hline Speeds of occupant from $10 \mathrm{~cm} / \mathrm{s}$ & 0 & 121.67 & 211.82 & 341.45 & 461.68 & 556.48 & 666.27 \\
\hline Speeds of occupant from $20 \mathrm{~cm} / \mathrm{s}$ & 0 & 61.47 & 107.18 & 171.85 & 233.33 & 280.43 & 335.53 \\
\hline Speeds of occupant from $35 \mathrm{~cm} / \mathrm{s}$ & 0 & 36.65 & 62.08 & 98.75 & 133.57 & 161.08 & 192.58 \\
\hline Speeds of occupant from $50 \mathrm{~cm} / \mathrm{s}$ & 0 & 25.30 & 44.40 & 70.35 & 94.50 & 112.90 & 135.47 \\
\hline Speeds of occupant from $75 \mathrm{~cm} / \mathrm{s}$ & 0 & 17.88 & 29.33 & 47.00 & 63.83 & 76.00 & 90.00 \\
\hline
\end{tabular}

Table 6. Simulation results in minutes for the first case, from the depth of 400 meters, for the elevator's speed from 7 $\mathrm{m} / \mathrm{s}$ and for the occupants speeds from $0.1 \mathrm{~m} / \mathrm{s}, 0.2 \mathrm{~m} / \mathrm{s}, 0.35 \mathrm{~m} / \mathrm{s}, 0.5 \mathrm{~m} / \mathrm{s}$ and $0.75 \mathrm{~m} / \mathrm{s}$

\begin{tabular}{|l|l|l|l|l|l|l|l|}
\hline Number of occupants & 120 & 100 & 80 & 60 & 40 & 20 & 0 \\
\hline Speeds of occupant from $10 \mathrm{~cm} / \mathrm{s}$ & 0 & 124.73 & 214.30 & 343.75 & 464.45 & 558.45 & 669.58 \\
\hline Speeds of occupant from $20 \mathrm{~cm} / \mathrm{s}$ & 0 & 64.57 & 106.33 & 173.10 & 233.87 & 282.05 & 336.02 \\
\hline Speeds of occupant from $35 \mathrm{~cm} / \mathrm{s}$ & 0 & 37.33 & 62.50 & 99.00 & 133.82 & 162.02 & 193.17 \\
\hline Speeds of occupant from $50 \mathrm{~cm} / \mathrm{s}$ & 0 & 26.37 & 43.67 & 69.95 & 94.78 & 113.07 & 135.95 \\
\hline Speeds of occupant from $75 \mathrm{~cm} / \mathrm{s}$ & 0 & 18.82 & 30.02 & 47.43 & 63.97 & 75.83 & 91.45 \\
\hline
\end{tabular}

Table 7. Simulation results in minutes for the first case, from the depth of 400 meters, for the elevator's speed from 5 $\mathrm{m} / \mathrm{s}$ and for the occupants speeds from $0.1 \mathrm{~m} / \mathrm{s}, 0.2 \mathrm{~m} / \mathrm{s}, 0.35 \mathrm{~m} / \mathrm{s}, 0.5 \mathrm{~m} / \mathrm{s}$ and $0.75 \mathrm{~m} / \mathrm{s}$

\begin{tabular}{|c|c|c|c|c|c|c|c|}
\hline Number of occupants & 120 & 100 & 80 & 60 & 40 & 20 & 0 \\
\hline Speeds of occupant from $10 \mathrm{~cm} / \mathrm{s}$ & 0 & 126.40 & 210.53 & 342.12 & 465.33 & 557.45 & 670.30 \\
\hline Speeds of occupant from $20 \mathrm{~cm} / \mathrm{s}$ & 0 & 62.50 & 106.77 & 172.27 & 235.83 & 280.03 & 336.73 \\
\hline Speeds of occupant from $35 \mathrm{~cm} / \mathrm{s}$ & 0 & 36.78 & 62.17 & 100.45 & 135.17 & 162.62 & 193.87 \\
\hline Speeds of occupant from $50 \mathrm{~cm} / \mathrm{s}$ & 0 & 26.43 & 44.33 & 71.00 & 95.00 & 113.55 & 135.08 \\
\hline Speeds of occupant from $75 \mathrm{~cm} / \mathrm{s}$ & 0 & 19.57 & 30.37 & 47.65 & 64.50 & 77.15 & 91.15 \\
\hline
\end{tabular}


Table 8. Simulation results in minutes for the first case, from the depth of 150 meters, for the elevator's speed from $10 \mathrm{~m} / \mathrm{s}$ and for the occupants speeds from $0.1 \mathrm{~m} / \mathrm{s}, 0.2 \mathrm{~m} / \mathrm{s}, 0.35 \mathrm{~m} / \mathrm{s}, 0.5 \mathrm{~m} / \mathrm{s}$ and $0.75 \mathrm{~m} / \mathrm{s}$

\begin{tabular}{|l|l|l|l|l|l|l|l|}
\hline Number of occupants & 120 & 100 & 80 & 60 & 40 & 20 & 0 \\
\hline Speeds of occupant from $10 \mathrm{~cm} / \mathrm{s}$ & 0 & 111.70 & 209.10 & 344.67 & 461.15 & 552.40 & 657.50 \\
\hline Speeds of occupant from $20 \mathrm{~cm} / \mathrm{s}$ & 0 & 56.93 & 105.72 & 173.42 & 230.57 & 277.77 & 334.70 \\
\hline Speeds of occupant from $35 \mathrm{~cm} / \mathrm{s}$ & 0 & 33.32 & 61.40 & 99.07 & 132.05 & 159.90 & 191.85 \\
\hline Speeds of occupant from $50 \mathrm{~cm} / \mathrm{s}$ & 0 & 23.28 & 43.23 & 69.88 & 92.62 & 112.32 & 134.10 \\
\hline Speeds of occupant from $75 \mathrm{~cm} / \mathrm{s}$ & 0 & 15.83 & 29.07 & 4.67 & 62.00 & 75.33 & 89.68 \\
\hline
\end{tabular}

Table 9. Simulation results in minutes for the first case, from the depth of 150 meters, for the elevator's speed from 7 $\mathrm{m} / \mathrm{s}$ and for the occupants speeds from $0.1 \mathrm{~m} / \mathrm{s}, 0.2 \mathrm{~m} / \mathrm{s}, 0.35 \mathrm{~m} / \mathrm{s}, 0.5 \mathrm{~m} / \mathrm{s}$ and $0.75 \mathrm{~m} / \mathrm{s}$

\begin{tabular}{|l|l|l|l|l|l|l|l|}
\hline Number of occupants & 120 & 100 & 80 & 60 & 40 & 20 & 0 \\
\hline Speeds of occupant from $10 \mathrm{~cm} / \mathrm{s}$ & 0 & 112.12 & 210.33 & 345.93 & 462.18 & 558.27 & 668.40 \\
\hline Speeds of occupant from $20 \mathrm{~cm} / \mathrm{s}$ & 0 & 56.97 & 105.97 & 173.30 & 229.87 & 334.85 & 336.53 \\
\hline Speeds of occupant from $35 \mathrm{~cm} / \mathrm{s}$ & 0 & 32.67 & 60.90 & 99.38 & 132.28 & 159.60 & 191.37 \\
\hline Speeds of occupant from $50 \mathrm{~cm} / \mathrm{s}$ & 0 & 23.13 & 43.02 & 69.67 & 93.30 & 112.05 & 134.15 \\
\hline Speeds of occupant from $75 \mathrm{~cm} / \mathrm{s}$ & 0 & 15.82 & 29.22 & 46.67 & 62.18 & 75.60 & 89.82 \\
\hline
\end{tabular}

Table 10. Simulation results in minutes for the first case, from the depth of 150 meters, for the elevator's speed from $5 \mathrm{~m} / \mathrm{s}$ and for the occupants speeds from $0.1 \mathrm{~m} / \mathrm{s}, 0.2 \mathrm{~m} / \mathrm{s}, 0.35 \mathrm{~m} / \mathrm{s}, 0.5 \mathrm{~m} / \mathrm{s}$ and $0.75 \mathrm{~m} / \mathrm{s}$

\begin{tabular}{|l|l|l|l|l|l|l|l|}
\hline Number of occupants & 120 & 100 & 80 & 60 & 40 & 20 & 0 \\
\hline Speeds of occupant from $10 \mathrm{~cm} / \mathrm{s}$ & 0 & 112.17 & 209.22 & 343.67 & 461.00 & 560.63 & 668.63 \\
\hline Speeds of occupant from $20 \mathrm{~cm} / \mathrm{s}$ & 0 & 57.62 & 105.87 & 172.45 & 230.87 & 279.52 & 335.15 \\
\hline Speeds of occupant from $35 \mathrm{~cm} / \mathrm{s}$ & 0 & 33.60 & 61.05 & 99.67 & 132.82 & 160.83 & 191.48 \\
\hline Speeds of occupant from $50 \mathrm{~cm} / \mathrm{s}$ & 0 & 23.73 & 42.98 & 69.68 & 93.18 & 112.77 & 134.33 \\
\hline Speeds of occupant from $75 \mathrm{~cm} / \mathrm{s}$ & 0 & 16.17 & 29.72 & 46.83 & 62.33 & 75.68 & 90.03 \\
\hline
\end{tabular}

Table 11. Simulation results in minutes for the second case, from the depth of 700 meters, for the elevator's speed from $10 \mathrm{~m} / \mathrm{s}$ and for the occupants speeds from $0.1 \mathrm{~m} / \mathrm{s}, 0.2 \mathrm{~m} / \mathrm{s}, 0.35 \mathrm{~m} / \mathrm{s}, 0.5 \mathrm{~m} / \mathrm{s}$ and $0.75 \mathrm{~m} / \mathrm{s}$

\begin{tabular}{|l|l|l|l|l|l|l|l|}
\hline Number of occupants & 120 & 100 & 80 & 60 & 40 & 20 & 0 \\
\hline Speeds of occupant from $10 \mathrm{~cm} / \mathrm{s}$ & 0 & 105.63 & 241.80 & 352.18 & 468.53 & 567.40 & 667.45 \\
\hline Speeds of occupant from $20 \mathrm{~cm} / \mathrm{s}$ & 0 & 51.87 & 120.65 & 177.50 & 230.98 & 286.03 & 334.15 \\
\hline Speeds of occupant from $35 \mathrm{~cm} / \mathrm{s}$ & 0 & 31.78 & 73.20 & 102.58 & 135.52 & 164.77 & 192.88 \\
\hline Speeds of occupant from $50 \mathrm{~cm} / \mathrm{s}$ & 0 & 22.32 & 50.82 & 72.65 & 95.45 & 116.17 & 134.95 \\
\hline Speeds of occupant from $75 \mathrm{~cm} / \mathrm{s}$ & 0 & 15.87 & 34.45 & 48.80 & 64.40 & 78.58 & 91.35 \\
\hline
\end{tabular}

Table 12. Simulation results in minutes for the second case, from the depth of 700 meters, for the elevator's speed from $7 \mathrm{~m} / \mathrm{s}$ and for the occupants speeds from $0.1 \mathrm{~m} / \mathrm{s}, 0.2 \mathrm{~m} / \mathrm{s}, 0.35 \mathrm{~m} / \mathrm{s}, 0.5 \mathrm{~m} / \mathrm{s}$ and $0.75 \mathrm{~m} / \mathrm{s}$

\begin{tabular}{|l|l|l|l|l|l|l|l|}
\hline Number of occupants & 120 & 100 & 80 & 60 & 40 & 20 & 0 \\
\hline Speeds of occupant from $10 \mathrm{~cm} / \mathrm{s}$ & 0 & 102.72 & 242.28 & 356.50 & 468.33 & 572.22 & 666.60 \\
\hline Speeds of occupant from $20 \mathrm{~cm} / \mathrm{s}$ & 0 & 55.18 & 128.92 & 178.33 & 235.52 & 287.13 & 334.95 \\
\hline Speeds of occupant from $35 \mathrm{~cm} / \mathrm{s}$ & 0 & 31.57 & 71.78 & 103.82 & 134.13 & 165.50 & 193.72 \\
\hline Speeds of occupant from $50 \mathrm{~cm} / \mathrm{s}$ & 0 & 23.42 & 52.15 & 72.00 & 93.82 & 116.67 & 135.73 \\
\hline Speeds of occupant from $75 \mathrm{~cm} / \mathrm{s}$ & 0 & 16.45 & 36.10 & 49.13 & 63.45 & 78.42 & 92.52 \\
\hline
\end{tabular}

Table 13. Simulation results in minutes for the second case, from the depth of 700 meters, for the elevator's speed from $5 \mathrm{~m} / \mathrm{s}$ and for the occupants speeds from $0.1 \mathrm{~m} / \mathrm{s}, 0.2 \mathrm{~m} / \mathrm{s}, 0.35 \mathrm{~m} / \mathrm{s}, 0.5 \mathrm{~m} / \mathrm{s}$ and $0.75 \mathrm{~m} / \mathrm{s}$

\begin{tabular}{|l|l|l|l|l|l|l|l|}
\hline Number of occupants & 120 & 100 & 80 & 60 & 40 & 20 & 0 \\
\hline Speeds of occupant from $10 \mathrm{~cm} / \mathrm{s}$ & 0 & 103.27 & 241.88 & 355.47 & 470.27 & 572.73 & 667.67 \\
\hline Speeds of occupant from $20 \mathrm{~cm} / \mathrm{s}$ & 0 & 55.38 & 122.82 & 180.00 & 231.78 & 288.38 & 337.35 \\
\hline Speeds of occupant from $35 \mathrm{~cm} / \mathrm{s}$ & 0 & 33.00 & 72.85 & 104.17 & 135.48 & 166.55 & 193.50 \\
\hline Speeds of occupant from $50 \mathrm{~cm} / \mathrm{s}$ & 0 & 24.50 & 52.53 & 74.00 & 95.92 & 117.37 & 137.58 \\
\hline Speeds of occupant from $75 \mathrm{~cm} / \mathrm{s}$ & 0 & 17.57 & 36.65 & 52.17 & 65.52 & 78.67 & 92.88 \\
\hline
\end{tabular}


Table 14. Simulation results in minutes for the second case, from the depth of 400 meters, for the elevator's speed from $10 \mathrm{~m} / \mathrm{s}$ and for the occupants speeds from $0.1 \mathrm{~m} / \mathrm{s}, 0.2 \mathrm{~m} / \mathrm{s}, 0.35 \mathrm{~m} / \mathrm{s}, 0.5 \mathrm{~m} / \mathrm{s}$ and $0.75 \mathrm{~m} / \mathrm{s}$

\begin{tabular}{|l|l|l|l|l|l|l|l|}
\hline Number of occupants & 120 & 100 & 80 & 60 & 40 & 20 & 0 \\
\hline Speeds of occupant from $10 \mathrm{~cm} / \mathrm{s}$ & 0 & 147.28 & 243.37 & 344.62 & 462.13 & 599.10 & 667.38 \\
\hline Speeds of occupant from $20 \mathrm{~cm} / \mathrm{s}$ & 0 & 51.70 & 121.28 & 177.37 & 231.63 & 285.52 & 334.23 \\
\hline Speeds of occupant from $35 \mathrm{~cm} / \mathrm{s}$ & 0 & 31.33 & 70.72 & 102.28 & 131.55 & 164.28 & 192.98 \\
\hline Speeds of occupant from $50 \mathrm{~cm} / \mathrm{s}$ & 0 & 22.65 & 51.48 & 73.17 & 95.58 & 115.98 & 135.02 \\
\hline Speeds of occupant from $75 \mathrm{~cm} / \mathrm{s}$ & 0 & 15.93 & 34.82 & 48.90 & 63.38 & 78.57 & 91.45 \\
\hline
\end{tabular}

Table 15. Simulation results in minutes for the second case, from the depth of 400 meters, for the elevator's speed from $7 \mathrm{~m} / \mathrm{s}$ and for the occupants speeds from $0.1 \mathrm{~m} / \mathrm{s}, 0.2 \mathrm{~m} / \mathrm{s}, 0.35 \mathrm{~m} / \mathrm{s}, 0.5 \mathrm{~m} / \mathrm{s}$ and $0.75 \mathrm{~m} / \mathrm{s}$

\begin{tabular}{|l|l|l|l|l|l|l|l|}
\hline Number of occupants & 120 & 100 & 80 & 60 & 40 & 20 & 0 \\
\hline Speeds of occupant from $10 \mathrm{~cm} / \mathrm{s}$ & 0 & 102.80 & 242.12 & 352.33 & 454.47 & 567.58 & 667.22 \\
\hline Speeds of occupant from $20 \mathrm{~cm} / \mathrm{s}$ & 0 & 53.02 & 120.13 & 176.73 & 233.52 & 286.15 & 333.80 \\
\hline Speeds of occupant from $35 \mathrm{~cm} / \mathrm{s}$ & 0 & 31.60 & 70.55 & 102.50 & 131.83 & 163.43 & 192.53 \\
\hline Speeds of occupant from $50 \mathrm{~cm} / \mathrm{s}$ & 0 & 22.53 & 49.50 & 72.05 & 92.82 & 115.17 & 135.32 \\
\hline Speeds of occupant from $75 \mathrm{~cm} / \mathrm{s}$ & 0 & 15.67 & 34.28 & 48.85 & 62.30 & 77.83 & 91.89 \\
\hline
\end{tabular}

Table 16. Simulation results in minutes for the second case, from the depth of 400 meters, for the elevator's speed from $5 \mathrm{~m} / \mathrm{s}$ and for the occupants speeds from $0.1 \mathrm{~m} / \mathrm{s}, 0.2 \mathrm{~m} / \mathrm{s}, 0.35 \mathrm{~m} / \mathrm{s}, 0.5 \mathrm{~m} / \mathrm{s}$ and $0.75 \mathrm{~m} / \mathrm{s}$

\begin{tabular}{|l|l|l|l|l|l|l|l|}
\hline Number of occupants & 120 & 100 & 80 & 60 & 40 & 20 & 0 \\
\hline Speeds of occupant from $10 \mathrm{~cm} / \mathrm{s}$ & 0 & 147.28 & 243.37 & 344.62 & 462.13 & 599.10 & 667.38 \\
\hline Speeds of occupant from $20 \mathrm{~cm} / \mathrm{s}$ & 0 & 51.70 & 121.28 & 177.37 & 231.63 & 285.52 & 334.23 \\
\hline Speeds of occupant from $35 \mathrm{~cm} / \mathrm{s}$ & 0 & 31.33 & 70.72 & 102.28 & 131.55 & 164.28 & 192.98 \\
\hline Speeds of occupant from $50 \mathrm{~cm} / \mathrm{s}$ & 0 & 22.65 & 51.48 & 73.17 & 95.58 & 115.98 & 135.02 \\
\hline Speeds of occupant from $75 \mathrm{~cm} / \mathrm{s}$ & 0 & 15.93 & 34.82 & 48.90 & 63.38 & 78.57 & 92.95 \\
\hline
\end{tabular}

Table 17. Simulation results in minutes for the second case, from the depth of 150 meters, for the elevator's speed from $10 \mathrm{~m} / \mathrm{s}$ and for the occupants speeds from $0.1 \mathrm{~m} / \mathrm{s}, 0.2 \mathrm{~m} / \mathrm{s}, 0.35 \mathrm{~m} / \mathrm{s}, 0.5 \mathrm{~m} / \mathrm{s}$ and $0.75 \mathrm{~m} / \mathrm{s}$

\begin{tabular}{|l|l|l|l|l|l|l|l|}
\hline Number of occupants & 120 & 100 & 80 & 60 & 40 & 20 & 0 \\
\hline Speeds of occupant from $10 \mathrm{~cm} / \mathrm{s}$ & 0 & 99.37 & 237.93 & 350.75 & 457.25 & 567.32 & 665.50 \\
\hline Speeds of occupant from $20 \mathrm{~cm} / \mathrm{s}$ & 0 & 51.95 & 118.18 & 174.90 & 230.03 & 284.17 & 333.35 \\
\hline Speeds of occupant from $35 \mathrm{~cm} / \mathrm{s}$ & 0 & 30.50 & 71.67 & 100.82 & 131.67 & 163.30 & 190.63 \\
\hline Speeds of occupant from $50 \mathrm{~cm} / \mathrm{s}$ & 0 & 20.73 & 48.57 & 70.98 & 91.82 & 114.63 & 133.63 \\
\hline Speeds of occupant from $75 \mathrm{~cm} / \mathrm{s}$ & 0 & 14.32 & 33.77 & 47.78 & 62.10 & 76.48 & 89.07 \\
\hline
\end{tabular}

Table 18. Simulation results in minutes for the second case, from the depth of 150 meters, for the elevator's speed from $7 \mathrm{~m} / \mathrm{s}$ and for the occupants speeds from $0.1 \mathrm{~m} / \mathrm{s}, 0.2 \mathrm{~m} / \mathrm{s}, 0.35 \mathrm{~m} / \mathrm{s}, 0.5 \mathrm{~m} / \mathrm{s}$ and $0.75 \mathrm{~m} / \mathrm{s}$

\begin{tabular}{|l|l|l|l|l|l|l|l|}
\hline Number of occupants & 120 & 100 & 80 & 60 & 40 & 20 & 0 \\
\hline Speeds of occupant from $10 \mathrm{~cm} / \mathrm{s}$ & 0 & 99.38 & 238.37 & 350.43 & 452.98 & 568.62 & 665.63 \\
\hline Speeds of occupant from $20 \mathrm{~cm} / \mathrm{s}$ & 0 & 52.37 & 118.42 & 176.15 & 233.08 & 284.27 & 333.47 \\
\hline Speeds of occupant from $35 \mathrm{~cm} / \mathrm{s}$ & 0 & 30.17 & 73.28 & 100.85 & 130.92 & 163.02 & 190.70 \\
\hline Speeds of occupant from $50 \mathrm{~cm} / \mathrm{s}$ & 0 & 20.43 & 49.32 & 70.87 & 92.83 & 114.47 & 133.72 \\
\hline Speeds of occupant from $75 \mathrm{~cm} / \mathrm{s}$ & 0 & 14.42 & 33.13 & 47.98 & 63.38 & 76.53 & 89.83 \\
\hline
\end{tabular}

Table 19. Simulation results in minutes for the second case, from the depth of 150 meters, for the elevator's speed from $5 \mathrm{~m} / \mathrm{s}$ and for the occupants speeds from $0.1 \mathrm{~m} / \mathrm{s}, 0.2 \mathrm{~m} / \mathrm{s}, 0.35 \mathrm{~m} / \mathrm{s}, 0.5 \mathrm{~m} / \mathrm{s}$ and $0.75 \mathrm{~m} / \mathrm{s}$

\begin{tabular}{|l|l|l|l|l|l|l|l|}
\hline Number of occupants & 120 & 100 & 80 & 60 & 40 & 20 & 0 \\
\hline Speeds of occupant from $10 \mathrm{~cm} / \mathrm{s}$ & 0 & 103.77 & 240.43 & 351.35 & 454.73 & 567.62 & 665.87 \\
\hline Speeds of occupant from $20 \mathrm{~cm} / \mathrm{s}$ & 0 & 50.22 & 119.70 & 175.87 & 229.07 & 284.05 & 333.68 \\
\hline Speeds of occupant from $35 \mathrm{~cm} / \mathrm{s}$ & 0 & 29.50 & 69.80 & 101.25 & 130.42 & 163.00 & 190.82 \\
\hline Speeds of occupant from $50 \mathrm{~cm} / \mathrm{s}$ & 0 & 21.67 & 51.22 & 71.45 & 95.12 & 114.55 & 133.92 \\
\hline Speeds of occupant from $75 \mathrm{~cm} / \mathrm{s}$ & 0 & 14.47 & 33.43 & 48.05 & 63.48 & 76.67 & 90.07 \\
\hline
\end{tabular}


Simulation results presented in tables imply the calculated times (in minutes) for determinate depth (150 meters, 400 meters or 700 meters), for the determinate elevator's speed $(5 \mathrm{~m} / \mathrm{s}, 7 \mathrm{~m} / \mathrm{s}$ or $10 \mathrm{~m} / \mathrm{s})$ and for noted speeds of occupants $(0.1 \mathrm{~m} / \mathrm{s}, 0.2 \mathrm{~m} / \mathrm{s}, 0.35 \mathrm{~m} / \mathrm{s}$, $0.5 \mathrm{~m} / \mathrm{s}$ and $0.75 \mathrm{~m} / \mathrm{s}$ ). This presentation of results provides presentation of moment state in mine - the number of occupants in mine, the number of evacuated occupants, calculated time for given conditions (depth, elevator speed, maximal number of occupants in elevator etc.)

\section{RESULTS ANALYSE}

The first case implied nine different scenarios and the realized results are presented in tables from table 2 to table 10 . The calculated evacuation times were not much different. The longest time needed for complete evacuation was 672.3 minutes and it was for the depth of 700 meters, for the elevator`s speed from $5 \mathrm{~m} / \mathrm{s}$ and for the occupants speeds from $0.1 \mathrm{~m} / \mathrm{s}$. The shortest time needed for complete evacuation was 89.68 minutes and it was for the depth of 150 meters, for the elevator`s speed from $10 \mathrm{~m} / \mathrm{s}$ and for the occupants speeds from $0.75 \mathrm{~m} / \mathrm{s}$. For the same depth and different elevators speeds, the evacuation times also were not much different. For example, for the depth of 700 meters, for different elevators speeds, the difference between the shortest times for evacuation was only few minutes (from 90.27 minutes to 94.10 minutes). For the depth of 400 meters, for different elevators speeds, the difference between the shortest times for evacuation was even smaller (from 90.00 minutes to 91.45 minutes). For the depth of 150 meters, for different elevators speeds, the difference between the shortest times for evacuation was also small (from $89.68 \mathrm{mi}-$ nutes to 90.03 minutes).

The second case also implied nine scenarios and the realized results are presented in tables from table 11 to table 19. The longest time needed for complete evacuation was 667.67 minutes and it was for the depth of 700 meters, for the elevator's speed from $5 \mathrm{~m} / \mathrm{s}$ and for the occupants speeds from $0.1 \mathrm{~m} / \mathrm{s}$. The shortest time needed for complete evacuation was 89.07 minutes and it was for the depth of 150 meters, for the elevator`s speed from $10 \mathrm{~m} / \mathrm{s}$ and for the occupants speeds from $0.75 \mathrm{~m} / \mathrm{s}$. And for this case, for the same depth and different elevators speeds, the evacuation times were not much different. For example, for the depth of 700 meters, for different elevators speeds, the difference between the shortest times for evacuation was only few minutes (from 91.35 minutes to 92.88 minutes). For the depth of 400 meters, for different elevators speeds, the difference between the shortest times for evacuation was (from 91.45 minutes to 92.95 minutes). For the depth of 150 meters, for different elevators speeds, the difference between the shortest times for evacuation was also small (from $89.07 \mathrm{mi}$ nutes to 90.07 minutes).

\section{CONCLUSION}

Any kind of accident in mine presents consequence. That consequence occurs for many different reasons. In many cases, that consequence implies death of miners. Generally, it is obvious that evacuation times realized by simulation for any depth was too long, in the sense of oxygen presence, carbon monoxide presence and other important gases, or for some other factors. Even if no explosion or some other kind of accident occurs, for example, the mere presence of toxic gases can lead to rapid intoxication and fast death of miners. Therefore, the most logical measure would be in the early warning systems, in the form of alarms and sensors. Besides, some physical kind of protection also must be realized (vents, barriers, oxygen stores and similar). All of these noted implies the strict work and technical discipline of all employed in mine.

The role of simulation software is also very important in the sense of safety prediction of potential evacuation scenarios. Of course, for mines with big depths, it is very hard to predict potential evacuation routes and calculate evacuation times, but for mines with less depth and more gaps, the prediction of evacuation scenarios, evacuation routes and calculation of evacuation times is very important as a safety measurement. Simulation software usage enables to predict proper evacuation scenario and strategy, to rehearse that scenario or scenarios on safe, secure and inexpensive manner. Because of all noted, simulation software must be mandatory engineering tool in the sense of safety and protection of human lives $[10,11]$.

\section{REFERENCES}

[1] [Internet], Preuzeto sa: https://www.6yka.com/novosti/najvece-rudarske-nesrece-na-svijetu-od-kine-francuske-turske-do-bih

[2] [Internet], Preuzeto sa: https://sr.wikipedia.org/srec/Rudarske_nesre\%C4\%87e_u_Srbiji

[3] [Internet], Preuzeto sa: https://www.telegraf.rs/vesti/srbija/2912613-rudnik-u-aleksincu-zatrpao-i-ubio90-rudara-pre-28-godina-usli-smo-tamo-danas-i-zatekli-prizor-od-kojeg-se-lede-kosti-foto

[4] [Internet], Preuzeto sa: https://www.kurir.rs/vesti/drustvo/1687084/7-najvecih-nesreca-u-sfrj

[5] Njekrasov V. B, General Chemistry, Third edition, Naučna knjiga, pp. 325, 326, 333, 342, 354, 673, Beograd, 1965. 
[6] Group of authors. Bad and dangerous materials, $\mathrm{Pu}-$ blisher working organisation Rad, pp. 94, 127-129, 474, 630, Belgrade, 1987.

[7] Radošević N, Chemists and technologist handbook, Technical book, pp. 1374, Belgrade, 1968.

[8] Aranđelović M, Jovanović J, Medicine of work, Medical Faculty in Niš, University of Niš, ISBN 8680599-52-2, pp. 125, 126, Niš, 2009.

[9] Thunderhead engineering. PyroSim User Manual, USA, 2019.
[10]Adjinski V, Mirakovski D, Despodov Z, Mijalkovski $S$, Simulation and optimization of evacuation routes in case of fire in underground mines, Journal of Sustainable Mining, Vol. 14, Issue 3, 2015, pp. 133 143.

[11]Tarshizi E, Kocsis C, Taylor D. Advanced approach to assess and improve underground mine evacuation using discrete-event simulation and animation, International Journal of Mining and Mineral Engineering 7(2):170, 2016, DOI: 10.1504/IJMME.2016.076500

\section{REZIME}

\section{SIMULACIJA EVAKUACIJE IZ RUDNIKA KAO SIGURNOSNA MERA}

Rudnici predstavljaju mesta gde se različite vrste ruda i minerala mogu eksploatisati za industrijske potrebe. Rudnici se otvaraju na lokacijama gde se rude ili minerali mogu naći u povećanim količinama, dovoljnim da ekonomski opravdaju eksploataciju. Podzemni rudnici se realizuju uglavnom za vrednije materijale, kao što su zlato, srebro, uranijum, ugalj itd. Da bi se došlo do sirovina, mnoge podzemne prostorije moraju biti iskopane, kao što su okna, galerije i sl. Iako su preduzete sve bezbednosne mere, nesreće se dešavaju u rudnicima i uzimaju mnogo žrtava. Jedna od najvažnijih stavki, ukoliko se nesreća desi, je evakuacija. Povređeni rudari iz rudnika moraju biti izvučeni što je pre moguće. Svaka greška za vreme evakuacije može dovesti do povećanja vremena potrebnog za evakuaciju i vrlo često do novih nesreća. Ovaj rad je napisan da pokaže primer evakuacije podzemnog rudnika.

Ključne reči: rudnik, evakuacija, simulacija, bezbednost 